\title{
50 years of Galtung and Ruge: Reflections on their model of news values and its relevance for the study of journalism and communication today
}

Stijn Joye ${ }^{1}$

Ghent University, Belgium

Ansgard Heinrich ${ }^{2}$

University of Groningen, The Netherlands

Romy Wöhlert ${ }^{3}$

University of Leipzig, Germany

doi: $10.5937 /$ comman 11-9514

Abstract: In 1965, Galtung and Ruge initiated a rich strand of academic research on the notion of news values and the practice of gatekeeping in a context of international news reporting. Since its publication, many scholars have criticized, revisited, and put their findings to the test, often leading to somehow conflicting conclusions. In general, some studies tend to confirm their findings while others have uttered methodological concerns or came up with new or additional sets of news factors, hence arguing for a further specification of the model. In recent years, scholars also pointed towards the increasing impact of digital media on journalistic practices of news selection. Likewise, new perspectives on global journalism were introduced into the debate. In this article, we bring together these different perspectives in order to inform a broad discussion on Galtung and Ruge's legacy for the field of communication sciences in general and studies on journalism and international news selection in particular. We first assess how Galtung and Ruge's hypotheses hold up in an era of unlimited data. Second, we reflect on the need to integrate changing societal and cultural contexts of news selection, production and reception to understand news values today. Third, with contemporary journalistic practices and research in mind, we suggest an agenda for the study of news values in an era of global journalism.

Keywords: Galtung and Ruge, news values, gatekeeping, news selection, international news, global journalism.

\footnotetext{
1 Contact with author: stijn.joye@ugent.be.

2 Contact with author: a.heinrich@rug.nl.

3 Contact with author: romy.woehlert@uni-leipzig.de.
} 


\section{Introduction}

While there were some predecessors such as Lippmann's essay on news from 1922 (Eilders, 2006: 6), it was the seminal and widely cited research article by Johan Galtung and Mari Holmboe Ruge (1965) that really started a rich tradition of academic discussion on the notion of news values and the practice of gatekeeping in a context of international news reporting. Since its publication in 1965, many scholars have criticized, revisited, and put their findings to the test, often leading to somehow conflicting conclusions. In general, some studies tend to confirm the original set of twelve news factors that are used to define newsworthiness (cf. Joye, 2010a; Golan, 2008). Others eventually came up with new or additional sets of news values and have argued for a further specification of the different aspects of the news process to which the broad term of 'news values' refers to (cf. Brighton \& Foy, 2007; Caple \& Bednarek, 2013; Harcup \& O’Neill, 2001; van Ginneken, 2005). Following this, several scholars have uttered their methodological concerns about an overall sense of 'uncertainty surrounding the empirical validity of both hypotheses and factors' (Hjarvard, 2002: 94; cf. Harcup \& O’Neill, 2001; van Ginneken, 2005). In recent years, scholars also pointed towards the increasing impact of digital media on journalistic practices of news gathering and selection (Heinrich, 2011) and acknowledged the emerging practice of gatewatching (Bruns, 2005). Likewise, new perspectives on global journalism (Berglez, 2013) and globally responsible journalism (Ward, 2011) were introduced into the debate on news values and the practice of gatekeeping. Beyond the debate on news values, international migration processes of the last decades have not only changed the social and cultural composition and integration policies of European societies but they also form an increasingly relevant structural context for the analysis of national and international news media coverage (Bayer, 2013).

In this article, we aim to bring together these different perspectives on the classic theory on gatekeeping in order to inform a broader discussion on Galtung and Ruge's legacy for the field of communication sciences in general and studies on journalism and international news selection in particular. What did fifty years of scholarly criticism learn us? Did their seminal work pass the test of time or should we rather regard it as a 'child of its time', hence outdated in terms of its appropriateness to today's (digital) news ecology? First, we will flesh out the model of Galtung and Ruge by means of a short literature review related 
to its key ideas and theoretical concepts, followed by a brief overview of the scholarly criticism. In a second part of this article, we present three takes on the central question about the model's relevance for contemporary research in the field of communication and journalism. First, we assess if and how Galtung and Ruge's model stands the test of time if their research was conducted today in an age of practically unlimited access to data. Second, we call for a stronger integration of changing societal and cultural contexts of news selection, production and reception in reflections on news values today. And third, with some main critiques of contemporary journalistic practices in mind, we suggest possible research directions to study news values in an era of global journalism.

\section{Gatekeeping and news factors: the model of Galtung and Ruge}

Generally acknowledged to be one of the oldest traditions of research within the field of journalism studies, research into gatekeeping and news selection appears to have lost some of its 'gravitas' in the last few decades (Hjarvard, 2002). Nevertheless, the concept of the journalist as a gatekeeper remains very relevant in today's media-saturated environment where news is ubiquitous and the danger of information overflow is real, implying the necessity of news selection in the journalistic news production process. Overlooking the field, one can identify two dominant approaches to gatekeeping research. On the one hand, we have the more sociological tradition focusing on the gatekeeper as "an individual or group [...] "in power" for making the decision between "in" or "out" (White, 1950, cited in Tumber, 1999: 66), his/her values and attitudes, and the impact of the media organization and the broader social context on the process of selection (e.g. Gieber, 1964; Shoemaker, 1991; White, 1950). On the other hand, studies have been looking into the factors or news values that determine whether an event is selected or not. Alongside Galtung and Ruge (1965) who are widely acknowledged as the founding 'father and mother' of this strand, Gans (1979), Wu (1998; 2000) and Golan (2008) have been influential in this field of research.

Published in 1965 in the Journal of Peace Research, 'The Structure of Foreign News' by Galtung and Ruge followed an essay in the same journal by Östgaard (1965) on the factors that influence news flows. However, it is the Galtung and Ruge article that is generally acknowledged to be the first empirical study into 
the criteria that the journalist as gatekeeper - implicitly or explicitly - applies when gathering and selecting the news. Their main question addressed how and why an event becomes news and thus has news value. Investigating the news coverage of three international political crises in Congo, Cuba and Cyprus by four Norwegian newspapers, Galtung and Ruge defined a taxonomy of twelve factors - hypotheses in their own words - that they regarded to be structurally determining the selection of news: frequency (when the event follows or fits the publishing frequency of the medium); threshold (absolute intensity and intensity increase); unambiguity; meaningfulness (relevance and cultural proximity); consonance (predictability and demand); unexpectedness (unpredictability and scarcity); continuity; composition (selection of an event based on the format or content of a news programme); reference to elite countries or people; presence of individuals (personification); and reference to something negative (1965: 65-71). The first eight news factors were considered to be universal while the last four were more culturally dependent or specific. In addition to the list of twelve factors, the authors stated a number of hypotheses. For one, the chance that an event is selected is higher when it abides to a larger number of news factors. Once selected, the features of the event that got it selected in the first place will be emphasized in the resulting news story, identified by Galtung and Ruge as a process of distortion. Finally, these processes of selection and distortion are replicated through all steps in the news production chain. The article concludes with an additional list of hypotheses about the possible combinations of factors and a call to journalists and policy-makers to try and counteract all twelve factors in order to reduce their (presumed) effects.

\section{Follow-up studies and scholarly criticism on Galtung and Ruge}

In the decades to come, scholars have put the findings of Galtung and Ruge to the test and found that the original results or hypotheses were not always confirmed, which consequently led to some criticism regarding the study's validity and methodological soundness (Hjarvard, 2002: 94). For instance, Hjarvard (2002: 94) pointed towards a neglect of the broader journalistic context and the particularities of the selection process while Rosengren (1970; 1974) stressed the importance to include extra-media data in the analysis of news selection practices (cf. infra). Others such as Tunstall (1971) and Harcup and 
O'Neill (2001) commented on the sample of the study for not incorporating domestic events and for its narrow focus on (three) crisis situations. Alongside methodological and conceptual criticism, alternative lists of news factors have been suggested while the initial set of factors has also been explored in more depth. Westerstahl and Johansson (1994), for example, further fleshed out the factor of meaningfulness. They found that the chance of selection depends heavily on the fact if a foreign event is relevant to and closely matches cultural and historical values of the home country. Others re-interpreted the factor of meaningfulness as an economic factor, hinting at trade relations and the level of economic development as the main determinants of international news coverage (Kim \& Barnett, 1996; Wu, 2000). In terms of new factors, many have put forward the factor of sensation, although there is little consensus as to how to define sensational news (Hendriks Vettehen, Nuijten \& Beentjes, 2005; van Ginneken, 2005).

Harcup and O’Neill (2001: 277) tested how the original study of Galtung and Ruge holds up in the new millennium and concluded that "[s]ome [news values] remain resonant today and can usefully be incorporated, if worded slightly different" such as magnitude, follow-up and bad news. In addition, they further proposed a contemporary set of news values, including the entertainment value of the event, the presence of celebrities and the factor of good news. According to Kennamer (1988: 120-121) all newly added news values could be replaced by an umbrella concept that he calls 'vividness'. It refers to so-called vivid information that he defines as the degree to which information evokes concrete images and generates personal emotions. It would take us too far to discuss all qualifications or additions to the field, but it is noteworthy to point out that some scholars such as Harrison (2006), Gans (1979) and Teunissen (2005) did not ignore more contextual or practical factors such as the availability of visual material as a selection factor. To conclude this brief overview, Golan (2008: 44-45) conducted a meta-analysis of the field and identified the following four key factors as basic predictors of news selection and coverage: "deviance (Shoemaker, Chang \& Brendlinger, 1986), relevance (Chang, Shoemaker \& Brendlinger, 1987), cultural affinity (Hester, 1973) and the prominence of the nation within the hierarchy of nations (Chang, 1998; Kim \& Barnett, 1996)". 
Despite the abundance of studies on news factors, this particular strand of research has always received a lot of criticism. Scholarly comments appear to converge on a number of issues. First, O'Neill and Harcup (2009) criticize the volatile nature of such lists of news values. In their view, many studies do not take into account the changing 'Zeitgeist' as news values are subject to changes in time and are highly dependent on contextual conditions related to the socalled media ecology of any given period. Likewise, McQuail (2000) and Hjarvard (2002: 94-95) questioned the assumption of many researchers in the field that it is at all possible to establish once and for all a final or absolute taxonomy of news factors. This assumes a high degree of uniformity in international news reporting and selection practices across different countries, time periods, media sectors and newsrooms. Secondly, McQuail (2000) states that such lists of criteria often fail to provide a full explanation of all the distortions and irregularities in compiling news as well as to expose the underlying ideological structures of the news values (see also van Dijk, 1988: 27-28; Westerstahl \& Johansson, 1994). In this respect, Hartley (1982: 80) argues that the news factors themselves "can actually disguise the more important ideological determinants of a story" (cf. infra). A third frequently expressed comment refers to an idea that was prominent in Galtung and Ruge's model. It concerns a difference in paradigms and beliefs with regard to the role of the journalists and news media. Are they just reporting on and covering events? Or are they constructing the world? Galtung and Ruge were criticized for an underlying belief "that there is a given reality out there in the "real world" that newsgatherers will choose either to admit or exclude" (Harcup, 2004: 33; McQuail, 2000: 279).

Overlooking the literature and the criticism, what often tends to be forgotten in the academic debate on the relevance of Galtung and Ruge's study is that the two authors themselves have actually made some very explicit claims regarding the value of their findings and the extent to which their study can or should be generalized. In what could be identified as a process of canonization, the article of Galtung and Ruge often appears to have been stripped over the years from such qualifications and subtle differences in meaning, resulting in a persistent image of the absolute landmark study and ultimate taxonomy of news values. However, in addition to the introduction statement that " $[\mathrm{n}]_{\mathrm{o}}$ claim is made for completeness in the list of factors or "deductions"” (Galtung \& Ruge, 1965: 64), throughout the text one finds ample acknowledgements by 
the authors of the study's hypothetical nature (e.g. page $66,70,80, \ldots$ ), even including clear disclaimers that "we shall not attempt to "axiomatize" on this meager basis" (71) and that "[i]t should be emphasized, however, that the present article hypothesizes rather than demonstrates the presence of these factors, and hypothesizes rather than demonstrates that these factors, if present, have certain effects among the audience" (85).

\section{A new look at an old theory}

Central to this article is a re-assessment of Galtung and Ruge's original model from a contemporary perspective. Dwelling on previous criticism, we explore three viewpoints or reflections on the present-day relevance and value of Galtung and Ruge's seminal study.

\subsection{The first landmark study with a major 'impact factor'}

The brief first point we would like to make is a methodological one and is related to a remarkable quote by Galtung and Ruge themselves: "It may be objected that what we have said is an artifact of the three crises we have picked for our sample. There is no other way of exploring this objection than by means of a new project" (1965: 80). Given the context of scholarly work in the 1960s and the (technological) resources available to them, this section dwells on the question what if Galtung and Ruge would have conducted their research today in an age of practically unlimited access to data? Would their hypotheses stand the test of time? While it is impossible to find an entirely faithful replication of their research, there are a number of recent studies that display a high similarity in terms of research questions, design and data. The study by Harcup and O'Neill (2001) is (rightfully) widely cited in this respect (cf. supra) but it diverges from the original study in its choice to include domestic events. Useful to test if Galtung and Ruge's framework still stands when researching international crises today is our previous work on the selection and coverage of international news by Belgian newspapers, with a focus on crises (natural and technological disasters) occurring between 1986 and 2006 (Joye, 2010b). Additionally, we incorporated in the research design an important point of criticism on the model of Galtung and Ruge by Karl E. Rosengren (1970). 
Rosengren $(1970 ; 1974)$ noted that research on gatekeeping and news selection would benefit from what he referred to as extra-media data or data gathered from outside and independent of news media such as official documents and databases. ${ }^{4}$ Only then, Rosengren argues, is it possible to reflect on differences between (an objective determination of) 'reality' and its mediated representation. This is a direct response to one of the research hypotheses and conclusions of Galtung and Ruge (1965: 71) that the new factors "produce an image of the world different from "what really happened"”. Identifying such distortion as selective inaccuracy requires a particular methodology that departs from "an appropriate basis of comparison and an objective determination of reality” (Gaddy \& Tanjong, 1986: 105), which was not part of Galtung and Ruge's research design. A similar argument is made by Hjarvard (2002: 94) who states that a content analysis of news coverage is not enough to determine if, for example, the dominant focus on elite individuals is a result of distortions in the news selection process or if it is due to these persons effectively playing a greater role in society.

Integrating these methodological remarks, we followed Rosengren's suggestion by making use of extra-media data of the international emergency events database EM-DAT (hosted by the Centre for Research on the Epidemiology of Disasters CRED) and so-called intra-media data from a quantitative content analysis of four Belgian newspapers (1986-2006). The EM-DAT database of international disasters can be considered as a database representation of 'reality', while in the case of data retrieved from the content analysis, we are dealing with a mediated representation of that same 'reality'. In the words of Rosengren (1974: 147-148), we can establish, on the one hand, a universe of events (extramedia data) and, on the other, a universe of news (reports on events). In order to explore the role of news factors and selective gatekeeping, both universes are compared on a number of news factors. Briefly summarized, the comparative analysis underwrites the premise that the news media's interpretation and representation of crises differs from the objective knowledge or data. The study reveals a high degree of selective inaccuracy and demonstrates that 70.8 per cent of all crisis situations occurring between 1986 and 2006 had been neglected by the newspapers, for the large part crises in less developed and non-western

\footnotetext{
4 The problem with integrating extra-media data in a research design aimed to investigate the role of news factors is that such data are not always available for each type of event or factor.
} 
countries. Disasters happening in neighboring countries, Western Europe or North America had a substantially greater chance of being selected and being covered more in depth than other crises. In addition, half of the editorial space in the Belgian newspapers was devoted to European crisis events, while eight out of ten disaster situations happened in Africa, Asia and Latin America. The distant crises in the peripheral South thus struggle for media attention unless they affect a huge number of (Western) people. These findings imply a rather distorted worldview that is characterized by a Eurocentric perspective fuelled by the two key news factors of proximity (meaningfulness) and severity of the disaster (threshold). In accordance with Galtung and Ruge, we found both factors to determine the process of news selection, while the amount of coverage was mainly driven by the element of proximity. However, we slightly re-interpreted the original factor of meaningfulness to incorporate the notion of proximity in its widest possible sense. Next to cultural proximity, the term refers to a number of (inter)related factors such as historical links, geographical distance, trade or economic relations, and psychological or emotional distance. In other words, it describes different expressions of a certain relationship of involvement. Furthermore, the study confirmed that news coverage of crises tends to focus on the dramatic event itself, with little attention to cause and aftermath (cf. news factor of frequency). Newspapers have a brief attention span, particularly regarding emergencies in developing nations (cf. news factor of reference to elite nations). Subsequent interviews with a selection of journalists underwrote the findings of the comparative analysis in terms of prevailing news factors in practices of gatekeeping (Joye, 2010b).

Alongside other studies (cf. supra), our research indicates the persistent relevance and empirical validity of the notion of news factors as laid bare by Galtung and Ruge in 1965. Of course, one must acknowledge the very speculative or hypothetical nature of the original study's objectives and its limitations to subjects of international news and crisis situations, which have received the rightful criticism as discussed above. Therefore, we would like to follow other scholars in their assessment of Galtung and Ruge's model as 'classic' (Tunstall, 1971: 20) and as 'a landmark in the scholarship of the media' (Watson, 1998 cited in Harcup \& O’Neill, 2001: 264) but simultaneously nuance that claim. It is without a doubt $a$ landmark, but not the absolute or even final one. Rather, it is that important first one which had a major impact, up till today. The study 
laid the foundations of a rich research tradition in the field of international news studies but its impact has not been restricted to academia alone. Nordenstreng (cited in Hjarvard, 2002: 93) for instance points to its influence on a policy level. Galtung and Ruge's work on gatekeeping and news factors has also informed debates on international news flows and inequalities, e.g. in studies conducted during the 1970s under the auspices of the New World Information and Communication Order NWICO movement.

Let us now turn to a second, more context-driven reflection on the value and legacy of Galtung and Ruge for journalism studies and gatekeeping research.

\section{2. (Changing) societal and cultural contexts of news selection, production and reception}

One necessary extension and specification of the original model of news values that needs to be added is a stronger integration of context, as has been pointed out before with regard to our suggestion to include extra-media data in the study on news values and gatekeeping. Critical remarks here, for instance, come from scholars such as Hjarvard who criticizes the neglect of broader journalistic context. Similar to that, Tunstall (1971:23) argued that " $\mathrm{i}] \mathrm{t}$ is probably not possible to examine news values in a meaningful way without also paying attention to occupational routines, budgets, the market, and ideology, as well as wider global cultural, economic and political considerations". Pointing towards the same direction, Bednarek and Caple (2012: 39-40) argued that news values should be observed in a broader sense, i.e. including the criteria or rules that journalists apply to determine what is 'news'; the (imagined) preferences of the expected audience about what is newsworthy (Richardson, 2007: 94); the qualities/elements that are necessary to make a story newsworthy (Cotter, 2010: 68); and the values by which events or facts are judged more newsworthy than others (Allern, 2002; Fowler, 1991; Hartley, 1982; Tunstall, 1996). Those values are thereby shared both by producers and audiences of news discourse (Bednarek \& Caple, 2012: 40). In a similar way, research focusing on ideological aspects of news values points out the cultural context of news. Here, Hall et al. (1978: 249) argued that "news values appear as a set of neutral, routine practices: but we need, also, to see formal news values as an ideological structure - to examine these rules as the formalization and operationalization of an ideology 
of news". Thus, taking up again the argument of Hjarvard (2002: 94) that the Galtung and Ruge model largely neglects the broader journalistic context and the particularities of the selection process, we suggest a stronger integration of journalistic practice with political, economic, social, global and other contexts. In order to do so, context should be observed on three levels: the individual, the institutional or organizational, and the societal level.

\section{Three levels of context}

On an individual level, we speak about journalistic ethics, ritualistic procedures of news production, as well as the (personal and professional) socialization of journalists and their concepts of self-definition and identity. Thus, the model of news values needs to include a cognitive perspective that integrates the relevance of journalists' beliefs and thus regards them as 'inter-subjective mental categories' (Fowler, 1991: 17) or 'internalized assumptions' (Cotter, 2010: 56) that people hold about qualities and aspects that make events or topics newsworthy. Those beliefs about newsworthiness can vary at times according to the individuals concerned (Bednarek \& Caple, 2012: 44). At the same time, journalistic practices are embedded in a wide range of discourses. Journalistic ethics and ritualistic procedures that try to convert these discourses into materialized practices for the individual journalist are necessary guarantees for the integrity, reliability, and status of journalists as 'truth speakers' or 'truth reporters' (Carpentier, 2007: 151). Therefore, a number of core concepts can structure the identity of journalists and these components can be so inherited in a journalist's identity that they might be taken-for-granted. Such key features for journalistic work may, for instance, be objectivity, autonomy and independence, resistance towards internal and external pressures, accountability, property, or the controlling function of journalists in a democratic setting (cf. 'watchdog of a state') (Carpentier, 2007: 151-152).

On the institutional or organizational level, we speak of 'internal' structural influences in the established institutions of news production, which form the professional institutional setting of journalistic work. This level includes aspects such as organizational structures but also media agendas. Journalists cannot detach themselves from media markets and the media organizations in which they operate - not even if they work as independent freelance journalists. Media 
organizations may have their own agenda(s), which can be based on inputs, ideas or goals of the media owners and editors in chief (Harcup \& O'Neill, 2001: 274-279), or may be influenced by advertisers (Brighton \& Foy 2007) or political agendas. Furthermore, journalists are also embedded in organizational structures that are often determined by commercial objectives. In those organizational settings, journalists also receive certain "professional socialization" (Carpentier, 2007: 151). For the analysis of news values, this calls for a perspective that explores the rootedness of the set of outlined news values of the Galtung and Ruge model in market dynamics, organizational work structures, or journalistic work ethics.

On the societal level, external influences such as value systems, norms, ideologies and the moral-political discourses, in which both journalists and media organizations are embedded, need to be taken into account in the study of news values. As Cultural Studies scholars such as Hall argue, a model like the one by Galtung and Ruge may help us to identify the formal elements within the construction of news and to identify routine practices. However, such models should be extended to consider the ideological context of news as well. Accordingly, news values may be regarded as a 'deep structure' or a 'cultural map' that journalists use to help them make sense of the world (Hall, 1973; Harcup \& O’Neill, 2001). An extended perspective on news value would take into consideration broader political and economic structures, and should observe the process of news selection as a social consensus among journalists (Caple $\&$ Bednarek, 2013; Hartley, 1982; Staab, 1990; Westerstahl \& Johansson, 1994). Accordingly, the 'inner discourse' of the newspaper is bound to the 'ideological universe of the society'. Therefore, news values can be conceptualized in terms of how newsworthiness is constructed through discourse (Bednarek \& Caple, 2012: 44-45).

Several studies have already approached the level of societal contexts, with a specific focus on value systems, ideologies and normative (political) discourses - aspects that may also form and shape the 'professional ideology' of journalists and newsmakers (Hall et al., 1978). With regard to value systems in general, one example would be the news coverage of scandals (cf. Thompson, 2000). Since scandals conflict with societal norms and values, they are publicly denounced in the news coverage. At the same time, by putting them in the media limelight, the underlying norms and values are negotiated and re-emphasized. 
Scandals can thus cause disruptions in a society and lead to necessary discourses to reassure or adjust commonly shared norms and values (Hondrich, 2002). Similar to that, Elliot and Greer (2010: 415) illustrate, that religious/cultural traditions and values can affect the news selection and production; while Scott (2006: 183-184) argues that patriotic pressures should be accounted for in contemporary studies of news values, agenda setting, and other newsroom practices.

\section{Accounting for social change}

A second specification we suggest to Galtung and Ruge's model is a stronger integration of the dimension of social change. This factor is especially interwoven with the societal context level. Social change is relevant when we discuss the differences between today's societies and the particular societal context in which Galtung and Ruge developed their model in 1965. Social change thereby refers to the level of media change (digitalization), technological changes (new communication structures such as the Internet), or changing media use in connection with that. Also, many factors in the news landscape are changing rapidly and continuously, such as the relationship between news providers (journalists) and news receivers (audiences), which is nowadays much more complex and polyvalent than before (Brighton \& Foy, 2007: 193). In addition, change also takes place on a cultural, economic, political and social level, for instance the change of political settings (East-West-Divide, Fall of the Iron Curtain, EU integration), or changes in the education, socialization and personal backgrounds of journalists. The above outlined approaches observe the level of societal context mainly from a synchronic perspective, i.e. taking into account value systems, ideologies and normative (political) discourses of a society at a certain point in time to explore the contexts of news production. We suggest to stronger value and apply the diachronic perspective in the analysis of news production mechanisms.

One example to illustrate the relevance of social change for the identification of news values is the change of compositions of societies. Global migration processes and new migration patterns in the last 60 years have led to significant changes in European societies like Germany, Great Britain or France. They have resulted in new policies, new legal regulations, social movements such as the 
civil rights movement in the 1960s/1970s, and thus a new awareness of equity and equality. Those societal and political changes also had an impact on the media system, for instance by changing production settings. Now, journalists with different ethnic, cultural and political backgrounds report about political, economic or social issues from different angles and new schemes of perception and categorization (cf. Geissler \& Pöttker, 2008; Weber-Menges, 2006). Galtung and Ruge only derived their theoretical conceptions from a single country study that also focused on a rather homogenous society (Norway) and on mainstream media outlets. In comparison, global migration trends have produced more heterogeneous societies and paved the ground for a growing number of diaspora media. Transnational connections and relations have become increasingly significant in light of what is viewed as the diminishing importance of national borders and the growing global linkages among non-state actors. Minorities and Diasporas turn to non-mainstream media that use minority languages and link up to particular communities. Also, the emergence of digital technologies enabled those media users to expand their communication activities to a global scale in order to maintain transnational communication links (Karim, 2011).

With Galtung and Ruge's model in mind, our suggestion for the study of news values would be to ask how news selection and production in ethnic media and/or by ethnic journalists differs from that of 'majority' media and journalists, and which 'new' news values could be identified in those contexts. Would a better integration of ethnic minorities in mainstream media production and representation extend or even change the composition of news values - or would those journalists simply adopt the 'old' media's news values and selection strategies (Georgiou, 2006: 81)? In addition, would new media agendas - shaped by new integration and diversity concepts and values - also change the journalistic conceptualisation of news worthiness?

The above raised criticisms and suggestions for additions to Galtung and Ruge's model do already touch upon one final question we want to address: where to go from here in journalism research on news values? This question becomes even more relevant when taking into account the profound changes of communication in an era of global information flows where production patterns of news as well as reception patterns are altered. 


\section{3. Suggestions for journalism research on news values in an era of global journalism}

Back in 1965, Galtung and Ruge noted that the more people are interlinked between and across borders and "the more nations are interdependent because of increasing efficiency of communication and military action, the more valid is the old sociological slogan about 'everything's relevance for everything else" (1965: 64) This slogan might have even more relevance today given the increased (digital) interconnectedness of the world in which these mediated representations (i.e. news) assist citizens to form their opinions about happenings near and far. Scholars such as Appadurai (1990) or Beck (2005) have repeatedly pointed out that in the networked era, social, cultural, economic or financial matters are interconnected across borders. In this environment, knowledge of the world is all the more essential. Along with this, the term global journalism has gained ground. Global journalism can refer to changing production mechanisms. It sketches the increase in global information flows and the development of 24/7 news channels that cater for global audiences, are characterized by global reach, and contribute to the development of a 'global public space' (Heinrich, 2015; Volkmer, 2005). Global journalism can also be interpreted as a 'news style' that pays justice to 'ever-more complex relations between peoples, places and practices' (Berglez, 2008: 848). The term is also used to describe a shift in journalistic orientations. Reese (2008: 241), for example, theorizes that following increased connectivity, journalists across the globe appear to influence each other and he predicts the development of a set of 'shared common norms and values adapted to the needs of a more globalized system.'

Yet, how do these different takes on global journalism relate to news values? More specifically, what role is assigned to news values in this era of global journalism? And which research approaches are needed to study the realities of newsroom practice and the use and impact of news values at news production desks? In this last part of our article, we want to draw attention to two research angles that deserve consideration when studying news values in light of discussions around global journalism: 1) the worth of examining news values in order to assess responsible reporting practices, and 2) the need to extend the study of news values beyond traditional newsrooms. 
Researching news values to identify responsible reporting practices in a digitally networked world

The many studies that have used Galtung and Ruge's news value model over the past 50 years as starting point to dissect news content (cf. sections above) all identified one major shortfall in news coverage, particularly with reference to crisis reporting: mainstream news media too often disseminate distorted worldviews. This critique was already visible in Galtung and Ruge's original work. Their contribution to the field is actually twofold: firstly, they have created the first scholarly model of news values. Yet, secondly, inherent in their model is a profound criticism of mainstream news media that is echoed till today. What might actually deserve the label of a 'classic' critique of news media coverage, does correlate with a popular call made by several scholars in recent years. Within a globalized sphere of news production, dissemination and reception, journalists are expected to take the role of the prime mediators and informants between cultures. Ward (2011: 247), for example, proposes a "globally responsible journalism" and demands "a cosmopolitan media that reports issues in a way that reflects this global plurality of views and helps groups understand each other better". Here, journalists 'should see themselves as agents of a global public sphere. The goal of their collective actions is a well-informed, diverse, and tolerant global "info-sphere" (2011: 16). Similarly, scholars such as Gans (2001) call for 'multiperspectival news', demanding that news coverage should represent the general public and make their views and voices heard to foster public discourse. Hafez (2009) states similar demands and even titled an article 'Let's improve global journalism!'.

Such calls for a reporting practice that explains an increasingly globalized world and mediates between cultures are necessary, but up till now largely of a normative nature. This discourse could do with more empirical examination of the dynamics at play in today's information exchange sphere to better connect the perspective of normative theory to concrete reporting practices. What makes and shapes a globally responsible journalism in the newsroom? Furthering and extending the study of news values and gatekeeping strategies on more empirical grounds is one way to contribute to this important discourse on globally responsible journalism. Think of some of the classic news factors as originally proposed by Galtung and Ruge. One of the most prominent news values cited with reference to global outlooks is the idea of meaningfulness or 
cultural proximity, hinting at the preference for selecting the culturally familiar. Also, the issue of contemporary news sourcing practices springs to mind, mirrored in news factors such as reference to elite nations and people. These news values directly link up to contemporary debates around journalistic practices where western-centric coverage driven by elite sourcing mechanisms is heavily criticized. More empirical and conceptual research into the concrete realities of newsrooms with regard to these news values can further the discussion on how to improve global journalism as it can help to critically assess newsroom routines that might contribute to a lack of contextualization and cosmopolitan perspective in news reporting. Studies of coverage concerned with current global crises spots are of just as much interest here as are studies that focus on what is not reported (and why certain topics are left out). Translated into empirical research, the call for globally responsible journalism can then be understood as a discussion on rethinking traditional news values.

However, in a digitally networked era, more and more news-producing players are situated outside of the realm of conventional journalistic production. In accordance, news values are notions that now have relevance and impact far beyond the boundaries of the journalistic newsrooms.

\section{Studying news values beyond classic newsrooms}

Within an increasingly open sphere of news production and exchange, the previously mentioned diaspora media are just one of the many players that have recently emerged on the map of contributors to journalism and information dissemination across the globe. Particularly the coverage of crises that are considered to have global impact such as the ongoing war in Syria, the fighting in the Ukraine or the terrorist activities of groups such as Boko Haram in countries such as Nigeria, demands a closer look at who reports what. Foreign journalists attached to mainstream news organizations operate side by side with independent freelance journalists or seek ways to collaborate with local journalists. At the same time, non-governmental organizations run their own websites including news feeds or use social media platforms such as Facebook or Twitter. Activist groups might use similar tools for public outreach and bloggers or so-called citizen journalists also share their accounts of the ongoing war in Syria or the fighting in Ukraine with the rest of the world. As these alternative media outlets have gained ground in digital, networked societies, it is vital to 
pay much more attention to their reporting practices and, respectively, the news values that guide these actors.

Thanks to the erosion of classic communication networks with fewer elites at the center of (international) reporting, concentrating only on the study of news values that drive production in professional newsrooms does exclude this vast array of other players that now are involved with global information provision. We suggest that contemporary research on news values must also include research on the selection and production mechanisms of all information producers involved in (crisis) reporting. Asking questions such as which news values rank high to drive their agendas, or what role does gatekeeping play in the reporting practices of these news producers is just as valid and necessary as the study of mainstream media outlets. Since those alternatives to the conventional newsroom increasingly professionalize their news routines, the study of their practices becomes ever more important. Just as journalism developed as a profession throughout the $20^{\text {th }}$ century, based on ideals of objectivity and the development of professional ethics (Schudson \& Anderson, 2009; Ward, 2009), these new players within the information sharing economy of the $21^{\text {st }}$ century are developing guidelines that assist their reporting routines. Yet, which values drive these alternative media producers? Does Galtung and Ruge's model apply, here, as well? Or might a study of these news providers yield different results and news factors? First studies have analyzed protest movements and their communication repertoire (e.g. Gerbaudo, 2012; Poell \& Borra, 2011) or examined how non-governmental organizations impact the international news landscape (Powers, 2015). This is a start in a much needed research direction. Yet, more research is desirable on news values, gatekeeping and agenda-setting strategies of these many (alternative) voices and organizations now occupying the digitally networked information sphere.

Tuchman (1978: 1) once wrote in Making the News:

"News is a window on the world. The view through the window depends upon whether the window is large or small, has many panes or few, whether the glass is opaque or clear, whether the window faces a street or backyard".

We would add here, that the view that users of news get also largely depends on the news values that the producers who look through this window adhere to. With today's changed media ecology in mind, it is pivotal to dedicate research to all these different producers involved. And it appears essential to compare the products and routines of these actors, especially in light of the fact that all these 
actors do influence each other (and, in turn, publics) within networked spheres of information exchange. Thus, researching production environments as well as news output of producers within and outside of classic newsrooms could help us to further assess which news values drive news routines in (digitized) information environments today. And studying the values guiding these diverse actors responsible for information gathering, selecting, producing and sharing does also link up to discussions of globally responsible journalism. Because in the end, the one question that drives research projects of this kind is: how can journalists insure an informed citizenry and act (globally) responsible.

\section{Concluding remarks}

50 years on, it is fair to say that as much as the thorough criticism of Galtung and Ruge's model is justified, their suggestions remain a very insightful and fruitful resource to discuss news values and their use in contemporary news production. Yet, both journalism practice as well as its scholarly study have, of course, evolved over the decades and will continue to do so. The taxonomy of news values as originally developed by Galtung and Ruge has inspired research agendas of scholars across the globe to study news content. And till date, their work is taught in classrooms worldwide to students of journalism, media and communication. Therefore, as Brighton and Foy (2007) stated, it is not necessary to fully redefine what news is or according to which values it is generated, but we should remain critical regarding the model's relevance and appropriateness to today's evolving news practices and ecology. Academically defined or derived news values such as those suggested by Galtung and Ruge in 1965, or those added to their list as possible extensions and specifications, can to some extend summarize points of awareness of the different contexts, pressures, motivations, or compromises that operate in the construction of news output. With the additional suggestions we presented in this article, we want to contribute to those efforts to recognize (changing) contexts, their complexities and different levels, and the changing societal and technological conditions of news selection and production.

Yet, the 50 year-old Galtung and Ruge's model and the many extensions of their model as well as the rich body of case studies that build on their work, can also be interpreted as a call for more empirical research on news production processes and an incentive to create more awareness of globally responsible reporting. As the wise saying goes, one is never too old to learn. 


\section{References}

Allern, S. (2002). Journalistic and Commercial News Values: News Organizations as Patrons of an Institution and Market Actors. Nordicom Review, 23(1-2): 137-152.

Appadurai, A. (1990). Disjuncture and Difference in the Global Cultural Economy. Theory, Culture \& Society, 7(2): 295-310.

Bayer, J. (2013). Media Diversity in Deutschland. Kulturwissenschaftliche Perspektiven auf journalistische Praxis. Accessed 18. 9. 2015. URL: http://edoc. ub.uni-muenchen.de/ 16086/1/Bayer_Julia.pdf.

Beck, U. (2005). Power in the Global Age. Cambridge and Malden, MA: Polity Press.

Bednarek, M. \& Caple, H. (2012). News Discourse. London: Continuum.

Berglez, P. (2008). What Is Global Journalism? Journalism Studies, 9(6): 845858.

Berglez, P. (2013). Global Journalism: Theory and Practice. New York: Peter Lang.

Brighton, P. \& Foy, D. (2007). News Values. Thousand Oaks: Sage.

Bruns, A. (2005). Gatewatching: Collaborative Online News Production. New York: Peter Lang.

Caple, H. \& Bednarek, M. (2013). Delving into the Discourse: Approaches to News Values in Journalism Studies and Beyond. Oxford: University of Oxford. Carpentier, N. (2007). Journalism, Media, and Democracy: Section Three: Introduction. In Cammaerts, B. \& Carpentier, N. (eds.), Reclaiming the Media. Communication Rights and Democratic Media Roles (pp. 151-156). Bristol: Intellect Books.

Chang, T. K. (1998). All Countries Not Created Equal to be News: World System and International Communication. Communication Research, 25: 528-566.

Chang, T. K., Shoemaker, P. \& Brendlinger, N. (1987). Determinants of International News Coverage in the US Media. Communication Research, 14: 396-414.

Cotter, C. (2010). News Talk. Investigating the Language of Journalism. Cambridge: Cambridge University Press. 
Eilders, C. (2006). News Factors and News Decisions. Theoretical and Methodological Advances in Germany. Communications, 31(1): 5-24.

Elliott, C. W. \& Greer, C. F. (2010). Newsworthiness and Islam: An Analysis of Values in the Muslim Online Press. Communication Quarterly, 58(4): 414-430.

Fowler, R. (1991). Language in the News: Discourse and Ideology in the Press. London: Routledge.

Gaddy, G. D. \& Tanjong, E. (1986). Earthquake Coverage by the Western Press. Journal of Communication, 36(2), 105-112.

Galtung, J. \& Ruge, M. H. (1965). The Structure of Foreign News. Journal of Peace Research, 2(1): 64-90.

Gans, H. (2011). Multiperspectival News Revisited: Journalism and Representative Democracy. Journalism, 12(1): 3-13.

Gans, H. (1979). Deciding What's News. New York: Vintage.

Geissler, R. \& Pöttker, H. (2008). Medien und Integration in Nordamerika. Bielefeld: Transcript.

Georgiou, M. (2006). Diaspora, Identity and the Media. Cresskill: Hampton Press.

Gerbaudo, P. (2012). Tweets and the Streets. Social Media and Contemporary Activism. London: Pluto Press.

Gieber, W. (1964). News is What Newspapermen Make it. In Dexter, L. A. \& White, D. M. (eds.), People, Society and Mass Communication (pp. 173180). New York: Free Press.

Golan, G. (2008). Where in the World is Africa? Predicting Coverage of Africa by US Television Networks. The International Communication Gazette, 70(1): 41-57.

Hafez, K. (2009). Let's Improve 'Global Journalism'! Journalism. Theory, Practice and Criticism, 10(3): 329-331.

Hall, S. (1973). The Determination of News Photography. In Cohen, S. \& Young, J. (eds.), The Manufacture of News. Social Problems, Deviance and the Mass Media (pp. 226-243). London: Constable.

Hall, S., Crutcher, C., Jefferson, T., Clarke, J. \& Roberts, B. (1978). Policing the Crisis: Mugging, the State and Law and Order. London: Palgrave Macmillan. Harcup, T. (2004). Journalism: Principles and Practice. London: Sage. 
Harcup, T. \& O’Neill, D. (2001). What is News? Galtung and Ruge Revisited. Journalism Studies, 2(2): 261-280.

Harrison, J. (2006). News. London: Routledge.

Hartley, J. (1982). Understanding News. London: Methuen.

Heinrich, A. (2011). Network Journalism. Journalistic Practice in Interactive Spheres. New York: Routledge.

Heinrich, A. (2015). Best Practices in the Network Journalism Sphere. In Craig, D. \& Lawrie, Z. (eds.), Ethics for Digital Journalists: Emerging Best Practices (pp. 31-44). London: Routledge.

Hendriks Vettehen, P., Nuijten, K. \& Beentjes, J. (2005). News in an Age of Competition: The Case of Sensationalism in Dutch Television News, 19952001. Journal of Broadcasting \& Electronic Media, 49(3): 282-295.

Hester, A. (1973). Theoretical Considerations in Predicting Volume and Direction of International Information Flow. Gazette, 19(4): 238-247.

Hjarvard, S. (2002). The Study of International News. In Jensen, K. B. (ed.), A Handbook of Media and Communication Research (pp. 91-97). London: Routledge.

Hondrich, K. O. (2002). Enthüllung und Entrüstung: Eine Phänomenologie des politischen Skandals. Frankfurt am Main: Suhrkamp.

Joye, S. (2010a). Around the World in 8 Pages? A Longitudinal Analysis of International News Coverage in Flemish Newspapers (1986-2006). Ghent: Academia Press.

Joye, S. (2010b). News Media and the (De)Construction of Risk: How Flemish Newspapers Select and Cover International Disasters. Catalan Journal of Communication and Cultural Studies, 2(2): 253-266.

Karim, K. H. (2011). Global Media Policy and Cultural Pluralism. In R. Mansell \& M. Raboy (eds.), The Handbook of Global Media and Communication Policy (pp. 276-292). Oxford: Wiley-Blackwell.

Kennamer, J. D. (1988). News Values and the Vividness of Information. Written Communication, 5(1): 108-123

Kim, K. \& Barnett, G. (1996). The Determinants of International News Flow: A Network Analysis. Communication Research, 23(3): 323-352.

McQuail, D. (2000). McQuail's Mass Communication Theory. London: Sage. 
O’Neill, D. \& Harcup, T. (2009). News Values and Selectivity. In Wahl-Jorgensen, K. \& Hanitzsch, T. (eds.), The Handbook of Journalism Studies (pp. 161-174). New York: Routledge.

Östgaard, E. (1965). Factors Influencing the Flow of News. Journal of Peace Research, 2(1): 39-64.

Poell, T. \& Borra, E. (2011). Twitter, YouTube, and Flickr as Platforms of Alternative Journalism: The Social Media Account of the 2010 Toronto G20 Protests. Journalism, 13(6): 695-713.

Powers, M. (2015). The New Boots On the Ground: NGO's in the Changing Landscape of International News. Journalism (published online first), 1-17.

Reese, S. D. (2008). Theorizing a Globalized Journalism. In Löffelholz, M. \& Weaver, D. (eds.), Global Journalism Research. Theories, Methods, Findings, Future (pp. 240-252). Malden, MA: Blackwell.

Richardson, J. E. (2007). Analysing Newspapers: An Approach from Critical Discourse Analysis. New York: Palgrave Macmillan.

Rosengren, K. E. (1970). International News: Intra and Extra Media Data. Acta Sociologica, 3(2): 96-109.

Rosengren, K. E. (1974). International News: Methods, Data and Theory. Journal of Peace Research, 11(2): 145-156.

Schudson, M. \& Anderson, C. (2009). Objectivity, Professionalism, and Truth Seeking in Journalism. In Wahl-Jorgensen, K. \& Hanitzsch, T. (eds.), The Handbook of Journalism Studies (pp. 88-101). New York, London: Routledge.

Scott, B. T. (2006). Patriotism as a News Value in Transitional Nations. In Schorr, A. \& Seltmann, S. (eds.), Changing Media Markets in Europe and Abroad. New Ways of Handling Information and Entertainment Content (pp. 183-195). Lengerich Westf: Pabst Science Publishers.

Shoemaker, P. J., Chang, T. K. \& Brendlinger, N. (1986). Deviance as a Predictor of Newsworthiness: Coverage of International Events in the US Media. Communication Yearbook, 10: 348-365.

Shoemaker, P. J. (1991). Gatekeeping. London: Sage.

Staab, J. F. (1990). The Role of News Factors in News Selection: A Theoretical Reconsideration. European Journal of Communication, 5(4): 423-443. 
Teunissen, F. (2005). Wat is Nieuws? Tegenstellingen in de Journalistiek. Den Haag: Boom Onderwijs.

Thompson, J. B. (2000). Political Scandal: Power and Visibility in the Media Age. Cambridge: Polity Press.

Tuchman, G. (1978). Making the News: A Study in the Construction of Reality. New York: The Free Press.

Tumber, H. (ed.) (1999). News: A Reader. New York: Oxford University Press. Tunstall, J. (1971). Journalists at work. London: Constable.

Tunstall, J. (1996). Newspaper Power: The New National Press in Britain. Oxford: Oxford University Press.

van Dijk, T.A. (1988). News Analysis: Case Studies of International and National News in the Press. Hillsdale, NJ: Erlbaum.

van Ginneken, J. (2005). Understanding Global News: A Critical Introduction. London: Sage.

Volkmer, I. (2005). News in the Global Public Space. In Allan, S. (ed.), Journalism. Critical Issues (pp. 357-369). Maidenhead: Open University Press.

Ward, S. (2009). Journalism Ethics. In Wahl-Jorgensen, K. \& Hanitzsch, T. (eds.), The Handbook of Journalism Studies (pp. 295-309). New York, London: Routledge.

Ward, S. (2011). Ethics and the Media. An Introduction. Cambridge: Cambridge University Press.

Weber-Menges, S. (2006). Die Entwicklung der Ethnomedien in Deutschland. In Geissler, R. \& Pöttker, H. (eds.), Integration durch Massenmedien: Medien und Migration im internationalen Vergleich (pp. 121-146). Bielefeld: Transcript.

Westerstahl, J. \& Johansson, F. (1994). Foreign News: News Values and Ideologies. European Journal of Communication, 9(1): 71-89.

White, D. M. (1950). The Gatekeeper: A Case Study in the Selection of News. Journalism Quarterly, 27: 383-390.

Wu, H. D. (1998). Investigating the Determinants of International News Flow. A Meta-Analysis. Gazette: The International Journal for Communication Studies, 60(6): 493-512.

Wu, H. D. (2000). Systemic Determinants of International News Coverage: A Comparison of 38 Countries. Journal of Communication, 50(2): 110-130. 